\title{
sciendo TRAFFIC SAFETY OF MAIN ROADS IN POLAND
}

DOI 10.2478/ntpe-2018-0008

\author{
dr hab. inż. Rafał Jurecki, prof. PSk \\ Kielce University of Technology, Poland \\ Doc Ing. Miloš Poliak, PhD. \\ University of Zilina, Slovak Republic
}

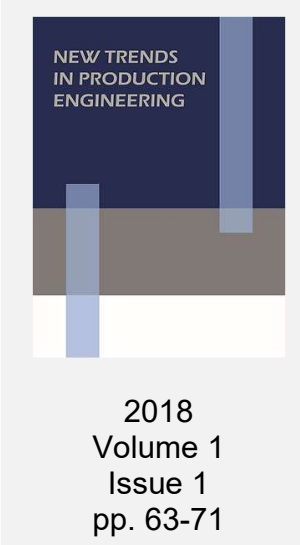

\begin{abstract}
The article presents an analysis of traffic safety on major communication routes in Poland. The total number of accidents in Poland has been compared and analysed in relation to the objectives in the context of the GAMBIT programs and the National Road Safety Program for the years 2013-2020. Analyses of the number of accidents in the years 2004-2017 have been presented in the article. A significant decrease in accidents has been demonstrated and annual changes determined, the value of which ranged from 12.15 to $6.74 \%$. The statistics on fatalities have been also analysed. A midyear change in the number of fatalities has been determined, which constitute $-4.4 \%$ in the analysed period. The data on the number of vehicles registered in Poland, which considerably affects traffic congestion, has been presented. In spite of this, there has been no increase in the number of accidents. The work compares changes in the length of the most important types of routes in Poland, as well as accidents and fatalities that occurred on them. With the decreasing overall number of accidents in Poland, there has been a noticeable drop in accidents per $100 \mathrm{~km}$ of road length also on these roads. The fatality rate per 100 accidents in Poland has been determined and the average value of this rate in 2017 was 8.64, while on the analysed roads it ranged from 12.3 to 14.6 .
\end{abstract}

Keywords: traffic safety, roads in Poland, accidents, analysis, statistics

\section{INTRODUCTION}

There are several thousand road accidents reported in Poland every year (Police Accidens Reports from 2004-2017). In 2010, the European Union adopted a very ambitious plan, which aims to reduce the number of fatalities on European roads in the current 2010-2020 decade (http://europa.eu; 2018). According to the sources of the European Commission (http://ec.europa.eu 2018), in 2017, 25,300 people died on European roads, nearly 300 less than in 2016 and 6,200 less than in 2010, which indicates that the goal may be difficult to achieve (Fig. 1) (http://europa.eu; 2018).

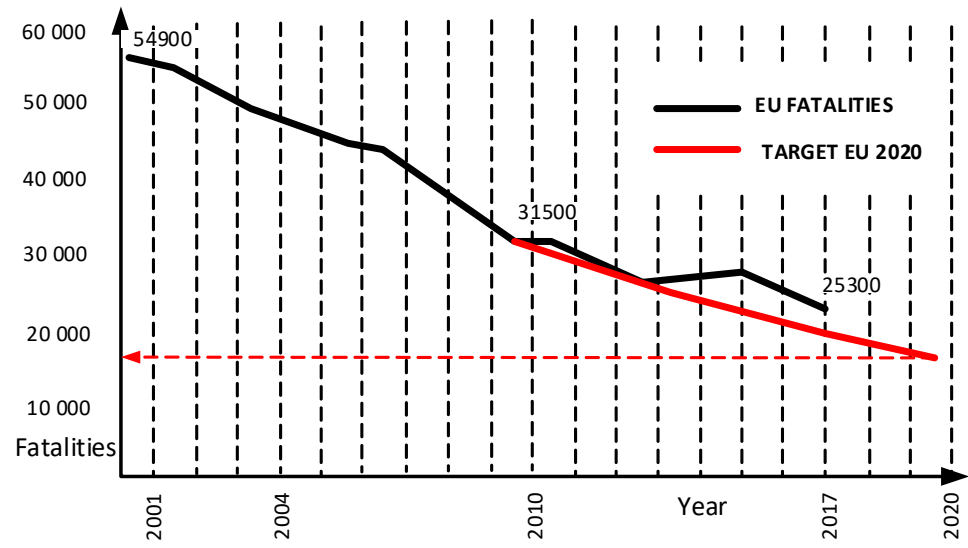

Fig. 1. List of accidents in Europe in the years 2001-2020

Although, European roads are the safest roads in the world (49 fatalities per million residents), there is still a significant diversity of road safety in different countries. In the EU, the best results 
have been recorded in Sweden (25), the United Kingdom (27) or the Netherlands (31), Poland is one of the leaders in this ranking (75), while Romania and Bulgaria have the worst rates with over 80 fatalities per million (http://ec.europa.eu; 2018). According to the European Transport Safety Council Report, in 2010-2016, the number of accidents in the EU decreased by an average of $18.7 \%$ and by as much as $53.4 \%$ in the entire $2001-2016$ period. In Poland, there was a decrease in the number of accidents by $22.5 \%$ and $45.3 \%$ respectively at that time. The record-breakers in the 2001-2016 period in terms of road safety improvement are Lithuania $73.4 \%$, Latvia $71.7 \%$ and Spain $67.4 \%$.

\section{ACCIDENTS ON POLISH ROADS}

Measures taken across the EU are to lead to both, a reduction in the number of road accidents and the consequences they cause. The measures of the European Union coincide with those developed in Poland - National Road Safety Program for the years 2013-2020, which is a continuation of the previous GAMBIT 2005 program (http://europa.eu; 2018).

For many years, the number of accidents in Poland has been gradually dropping. The year 1997, when nearly 67 thousand accidents were recorded, was record-breaking in this respect (Fig. 2).

\section{Number of accidents}

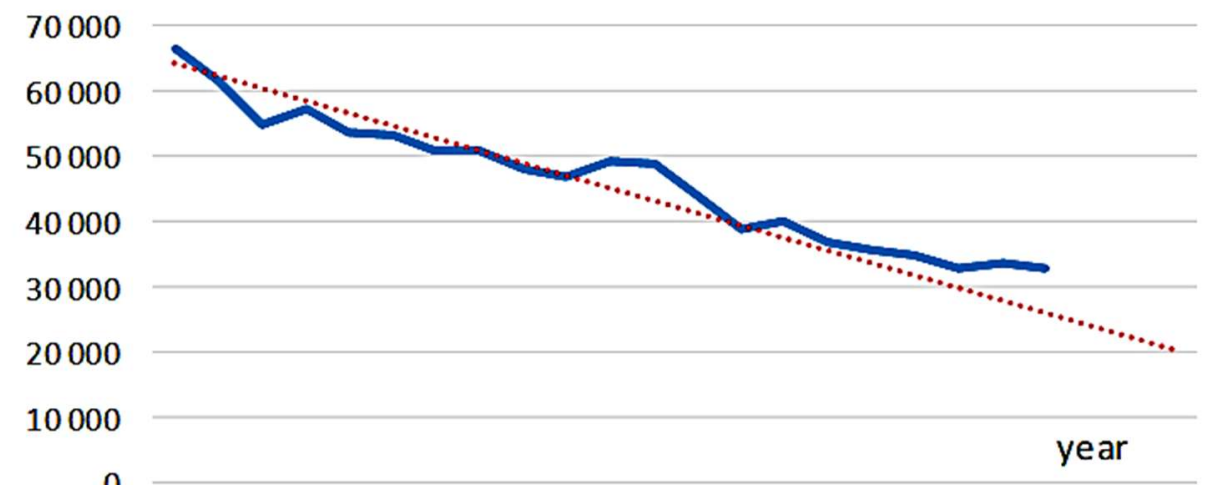

0
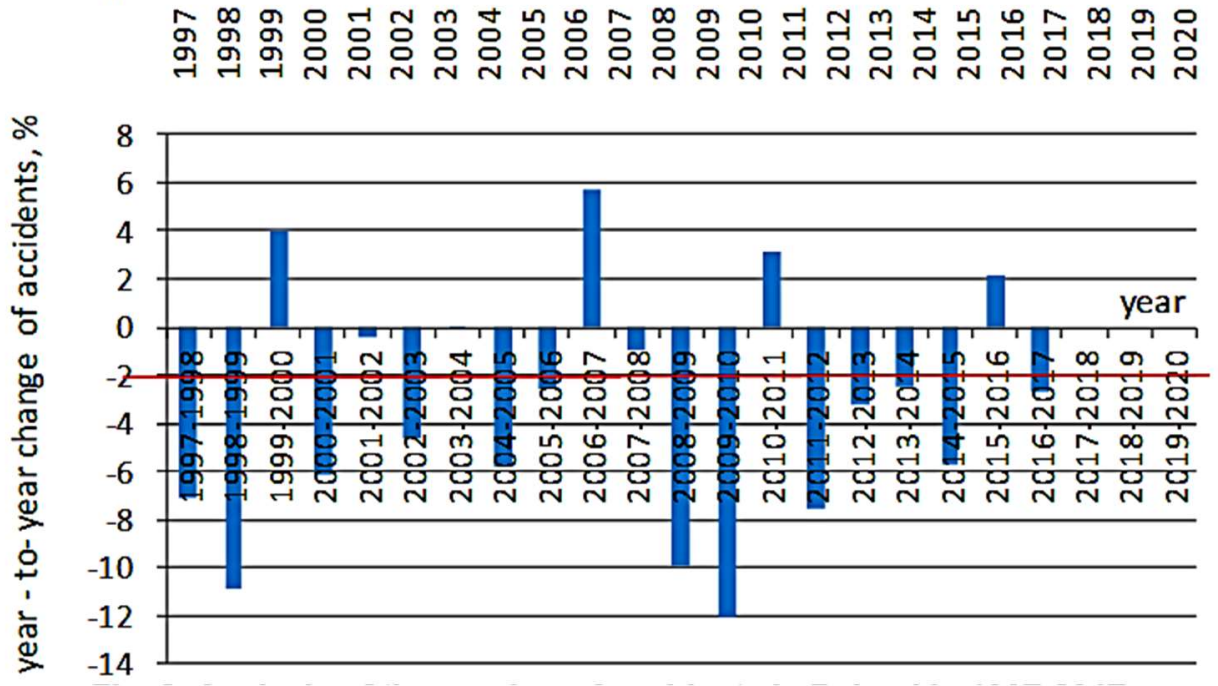

Fig. 2. Analysis of the number of accidents in Poland in 1997-2017

Since then, the number of accidents has been decreasing. If the current tendency continues, it is expected to drop to about 26,000 in 2020 . It is worth paying attention to the analysis of changes in the number of accidents year-to-year. The average drop in the number of accidents was $3.36 \%$, although there were also very significant declines in the analysed period, e.g. in $2010-12.13 \%$ or increases $5.67 \%$ in 2007 . In the analysed period, there was an increase in the number of accidents only within four years $(2000,2007,2011$ and 2016).

Along with the change in the number of road accidents, the number of casualties also decreased. The number of fatalities with the record-breaking number of 7,311 in 1997 dropped to 2,831 in 
2017. An annual average drop in the number of fatalities was achieved over the years 19972017, amounting to $-4.4 \%$ e.g. in $2009-15.9 \%$ or increases $5.29 \%$ in 2002 (Fig. 3). It is worth emphasising here that a significant reduction in the number of fatalities was assumed in the GAMBIT 2005 program for the years 2005-2013. Unfortunately, as shown in the graph presented in Figure 3, these goals have not been achieved. If we analyse the data for 2010, we can see how far the goal, set by the EU, has been achieved (http:www.krbrd.gov.pl; 2018).
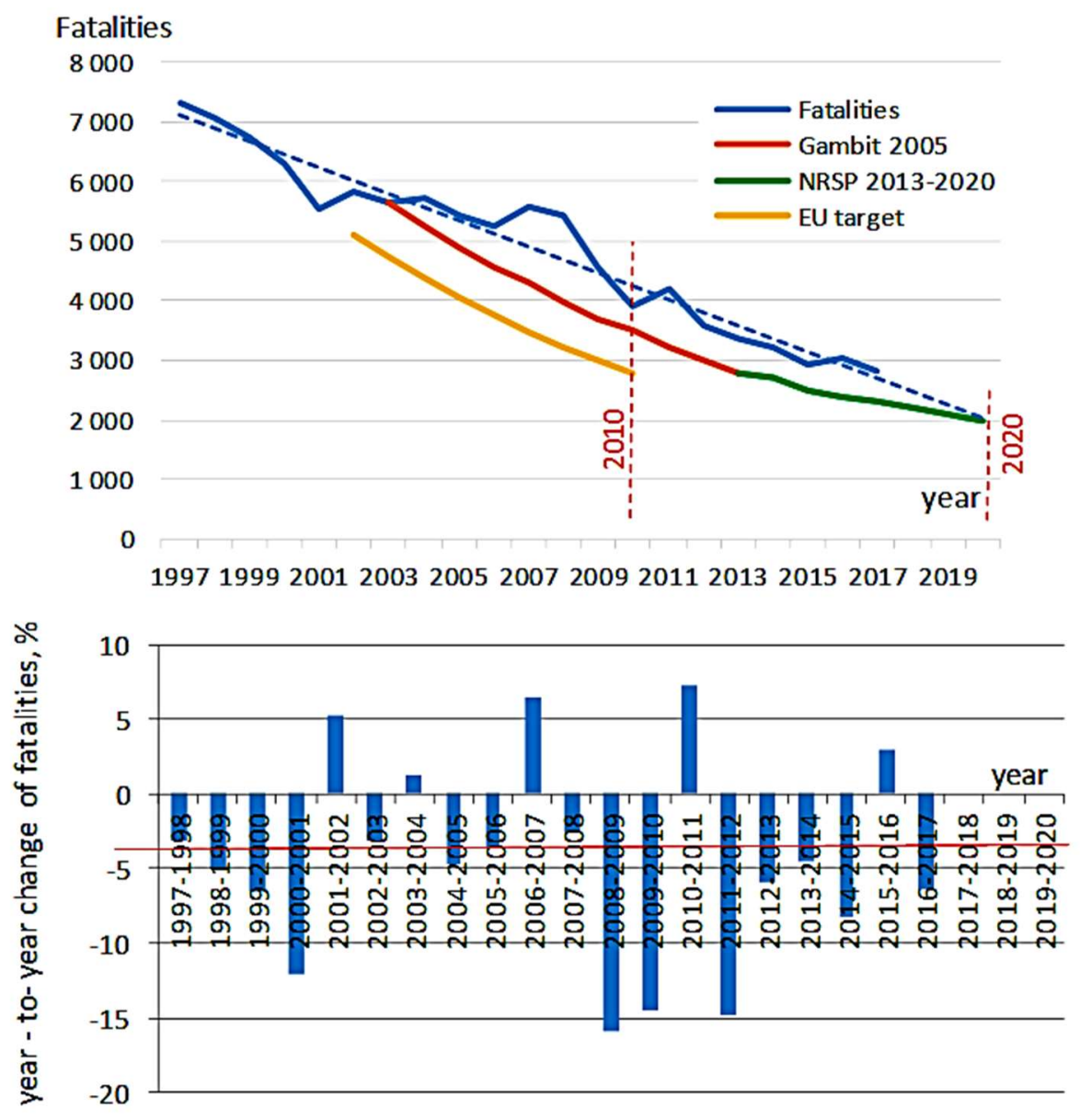

Fig. 3. Analysis of the number of fatalities in Poland in 1997-2017

The continuation of the Gambit program was the already mentioned NRSP 2013-2020, which continues the far-reaching vision of security called the "Vision Zero." It is assumed to reach the "zero fatalities on roads in the future." The program assumes the reduction in the number of fatalities by $50 \%$ in relation to 2010 , i.e. to the level of approx. 2,000 people. If the trend determined for the actual accident data continues, this target could be achieved in 2020 (http:www.krbrd.gov.pl; 2018).

This does not mean, however, that the level of road safety is satisfactory, because Poland is still on the disgraceful list of Europe in this respect. When analysing accident statistics, it is worth considering the number of vehicles travelling on Polish roads (Fig. 4).

The Figure 4 shows the number of motor vehicles in Poland. In the last 20 years, the number of motor vehicles has increased by $137 \%$, passenger cars by $160 \%$, and trucks by $115 \%$ (Police Accidens Reports from 2004-2017, http://info.car; 2018, https://histmag.org; 2018). The average increase in the number of vehicles in the analysed period was $4.37 \%$. The highest growths were recorded in the years 2006-2008. 


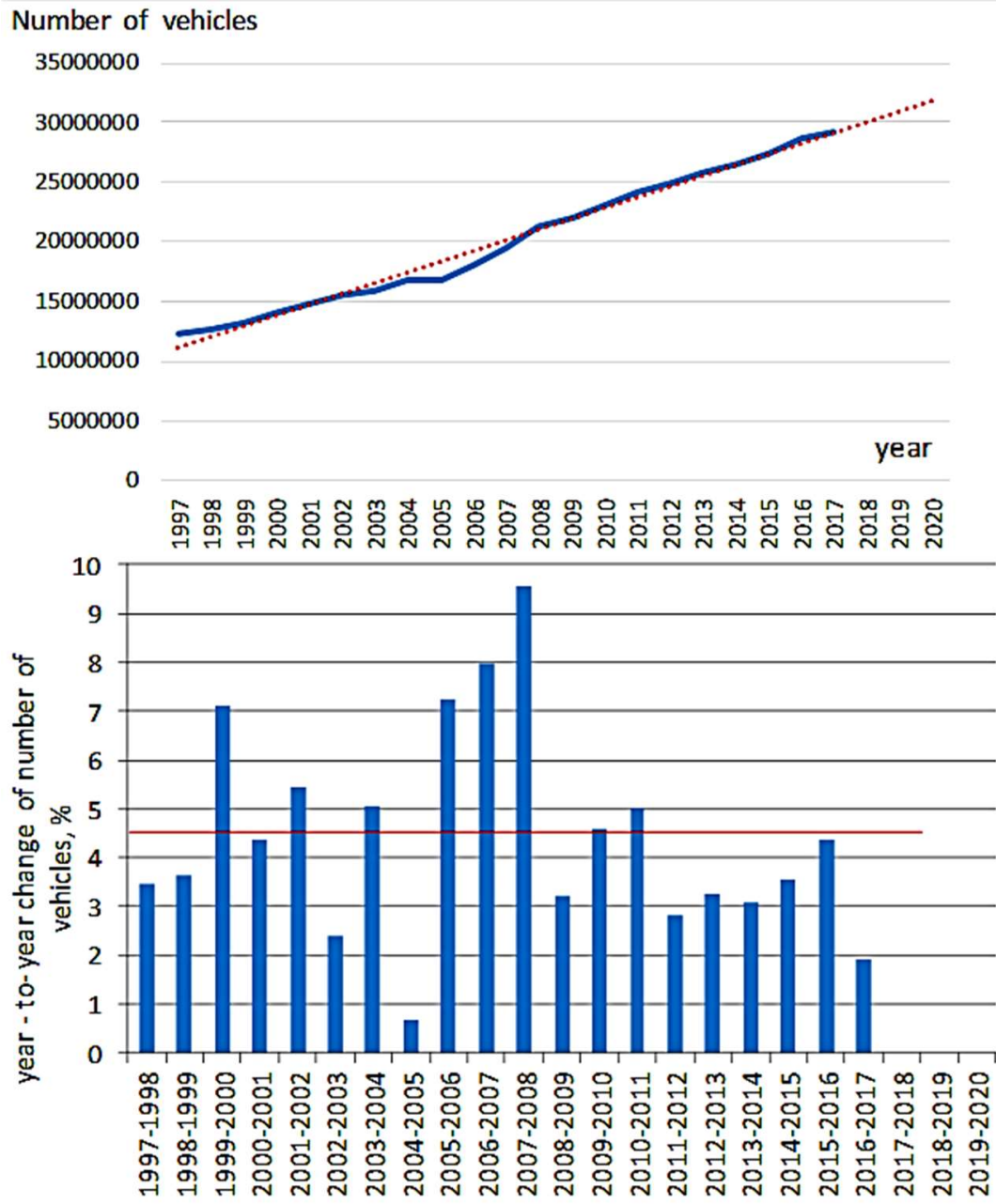

Fig. 4. Number of vehicles in Poland in 1997-2017

\section{NATIONAL ROADS, EXPRESSWAYS AND MOTORWAYS}

The condition of road infrastructure may be one of the factors affecting road safety. Infrastructure should ensure not only higher speeds, comfort of travel, but above all traffic safety. Hence, there are many studies conducted in this field (Jurecki R. et al.; 2014, Jurecki et al.; 2017, Jurecki R. \& Stańczyk T.L.; 2018). Roads should eliminate possible driver errors and minimize the effects of possible traffic incidents (Jurecki R. et al.; 2014). The layout of the road network in Poland has undergone many changes over the years.

The length of all public roads in Poland in the years 2004-2017 increased by a little over 40,000 $\mathrm{km}$ and exceeded $420,000 \mathrm{~km}$, an increase of $10 \%$. It is important to realize, however, that the main traffic takes place on the main roads - national roads, expressways and motorways (Jurecki R. et al.; 2014).

In case of national roads, the increase in their length was slightly higher and was about $15.7 \%$. National roads considerably fortify the expressway and motorway network despite the fact that they constitute only about $4.5 \%$ of all public roads. At the end of 2017 , the length of national roads in good condition - at a desirable level - constituted around $60 \%$. Over $40 \%$ of national roads were in a warning and critical condition, of which more than one third, i.e. $14.5 \%$, was in a bad condition (critical level) (https://www.gddkia.gov.pl; 2018). The Figure 5 shows the existing network of national roads.

The length of expressways and motorways has significantly increased in recent years. In 2004, the network of these roads was small, and their length was 223 and $535 \mathrm{~km}$ respectively. At the end of 2017 , the increase in the length of motorways (compared to 2004 ) was $206 \%$ (1,638 km) and expressways $712 \%(1,811 \mathrm{~km})$. The Figure 6 shows the target network of such roads. It is worth considering whether, and if so, how the changes in the quality of road infrastructure has affected the occurrence of road accidents. 


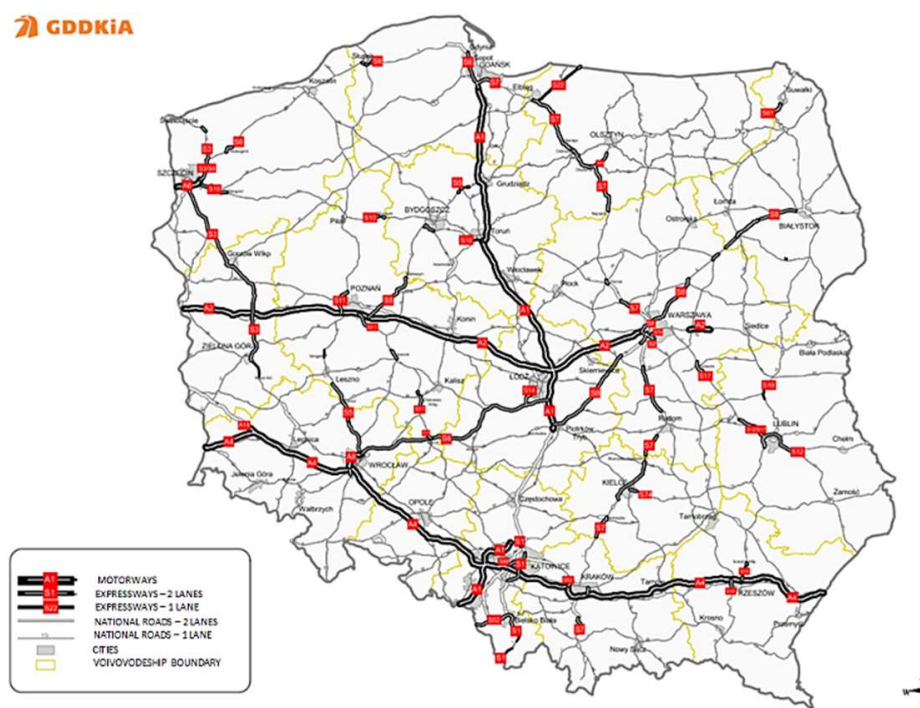

Fig. 5. The existing network of national roads in Poland on 24/05/2018 Source: (https://www.gddkia.gov.pl; 2018)

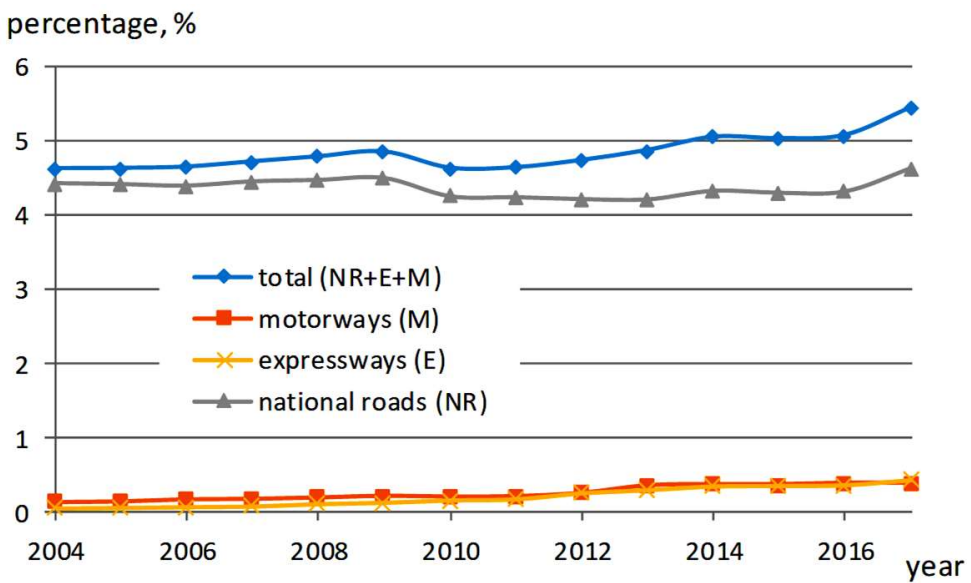

Fig. 6. The length of national roads (NR), expressways (E) and motorways $(\mathrm{M})$ in relation to all public roads

Analysing the accident statistics on these three types of roads, the length of which in relation to all public roads in Poland is constantly increasing and reached the level of $5.4 \%$ in 2017 (Fig. 6), it can be noted that the increase in accidents on these roads is decreasing (Fig. 7).

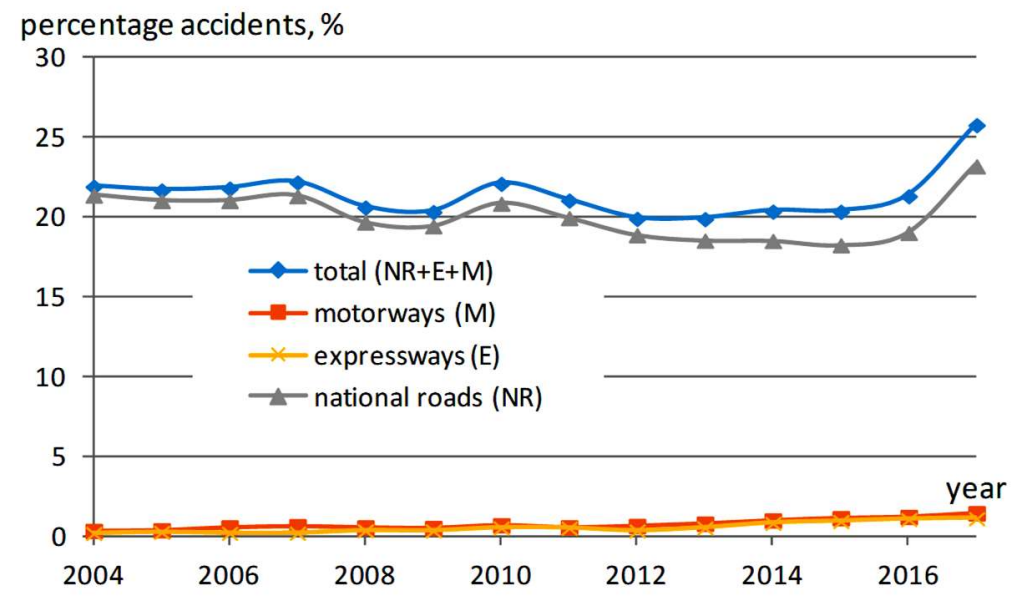

Fig. 7. The number of accidents in 2004-2017 on different roads 
It is true that in 2017 there was a temporary growth, but to put forward the thesis that this is the beginning of transformation in the current tendency one should wait for the data from the next years. However, what is noticeable is the fact that despite the increase in the number of accidents on national roads in the last two years (and especially in 2017), the number of fatalities on these roads is not increasing (Fig. 8).

The data shows that the number of recorded accidents varies at around $20 \%$ and fatalities at around $37 \%$ on roads the share of which in the public road network is only $5.4 \%$ This is an undeniable fact, but in order to make a full analysis one should refer this data to many other factors, such as traffic intensity on these roads.

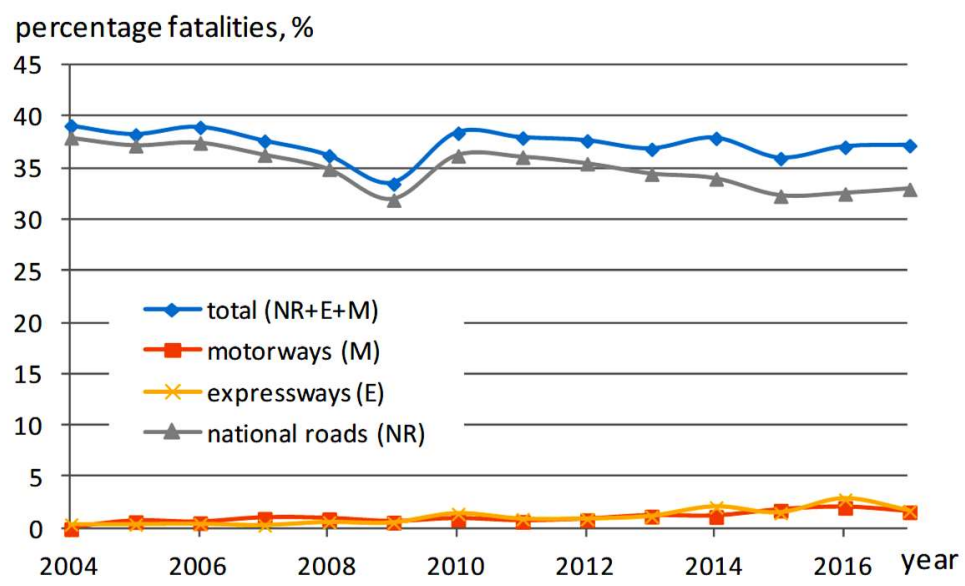

Fig. 8. The number of fatalities in 2004-2017 on different roads

In countries where data on accidents, causalities and road traffic intensity are available, Euro RAP maps are developed, which can facilitate the road safety evaluation. Such maps give an impartial view of the roads where the risk of life loss and damage to health is the greatest. As presented in the last Euro RAP report for the years 2010-2012 (http://www.eurorap.org; 2018), the Figure 9 in it shows that over $60 \%$ of roads in Poland are high-risk roads marked in red and black.

There are increasingly more roads with the level of risk accepted by the EU (green and yellow colours). It is easy to notice that motorways and expressways are relatively the best in this regard.

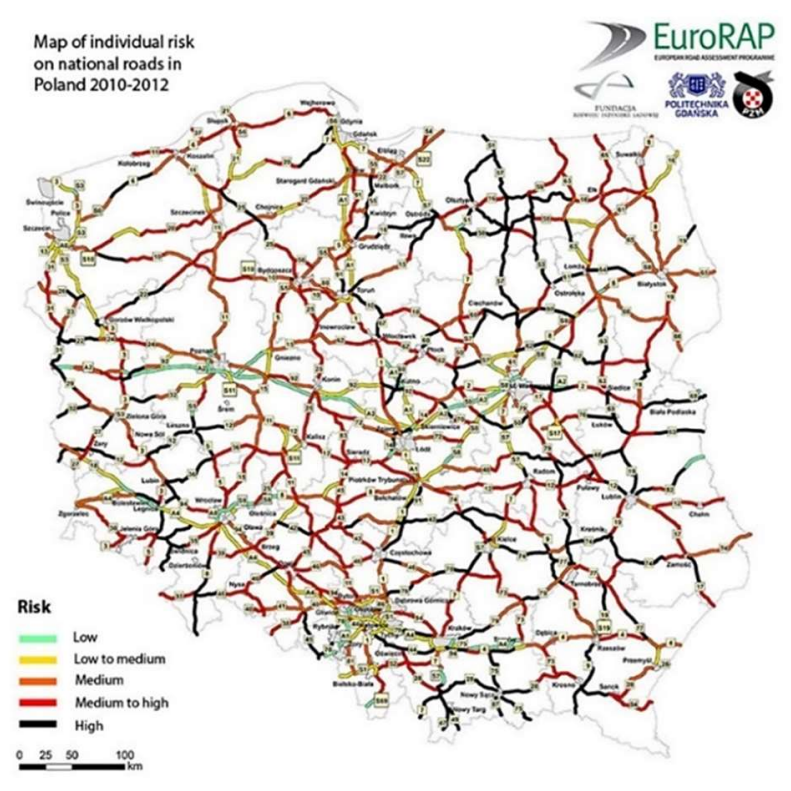

Source: (https://nik.gov.pl; 2018)

Fig. 9. EuroRAP Risk Map for the years 2010-2011 


\section{TYPE OF ROADS AND EFFECTS OF ACCIDENTS}

With the increase in the length of the analysed roads: national roads, expressways and motorways, the number of accidents that have occurred on them has decreased in recent years (Fig. 10)

The national roads, as mentioned above, account for $4.5 \%$ of public roads in Poland, $0.43 \%$ are expressways and motorways constitute only $0.39 \%$ of the total number of public roads. If we refer the number of accidents that have occurred on these roads to the length of these roads, it will turn out that the relatively most dangerous roads are national roads, where an increase in the number of accidents has been recorded since 2015 (Police Accidens Reports from 20042017).

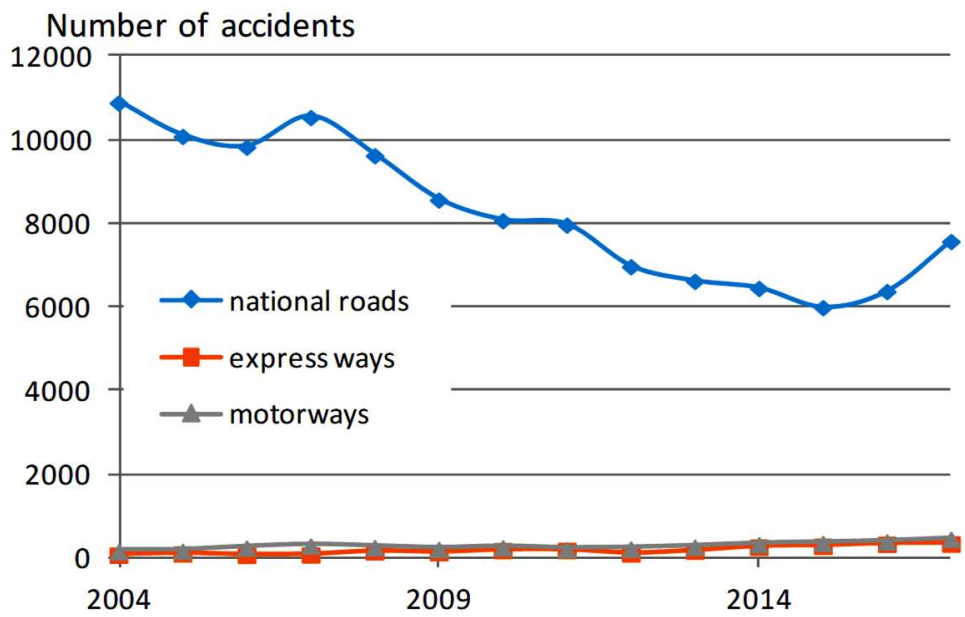

Fig. 10. Number of accidents on national roads, expressways and motorways

If we compare these data with the lengths of these roads (Fig. 11), we see downward trends in the analysed period. In 2017, there were nearly 40 accidents per $100 \mathrm{~km}$ of national roads, 30 accidents on motorways and 20 on expressways. However, if we analyse long-term trends, it can be noticed that the number of accidents occurring on three types of analysed roads is similar and fluctuates between 20 and 40 . The spread of values around the trend line on national roads determined by the coefficient of determination is the smallest $R^{2}=0,9$, on motorways is $R^{2}=$ 0,68 and $R^{2}=0,47$ on expressways.

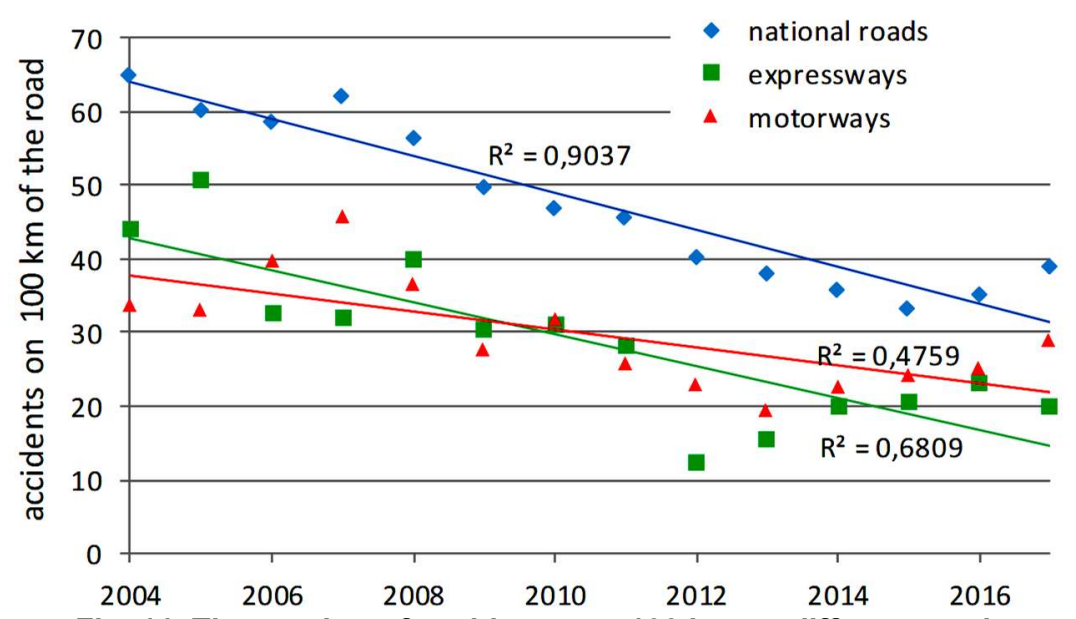

Fig. 11. The number of accidents per $100 \mathrm{~km}$ on different roads

The NIK (The Supreme Audit Office) report on accidents from 2017 indicated that in the case of motorways and expressways, there are even five times more casualties compared to the same statistics conducted on other public roads, of which there are over 420,000 in Poland (Sobolewski M.; 2015). Indeed, if the number of accidents is related to the length of all public 
roads, it will turn out that there are only 8 accidents per $100 \mathrm{~km}$ of such roads. In this case, how to evaluate RAP reports that indicate such roads as relatively most-dangerous? If we analyse fatalities in accidents (Fig. 12) with reference to the length of these roads, there is a systematic decline.

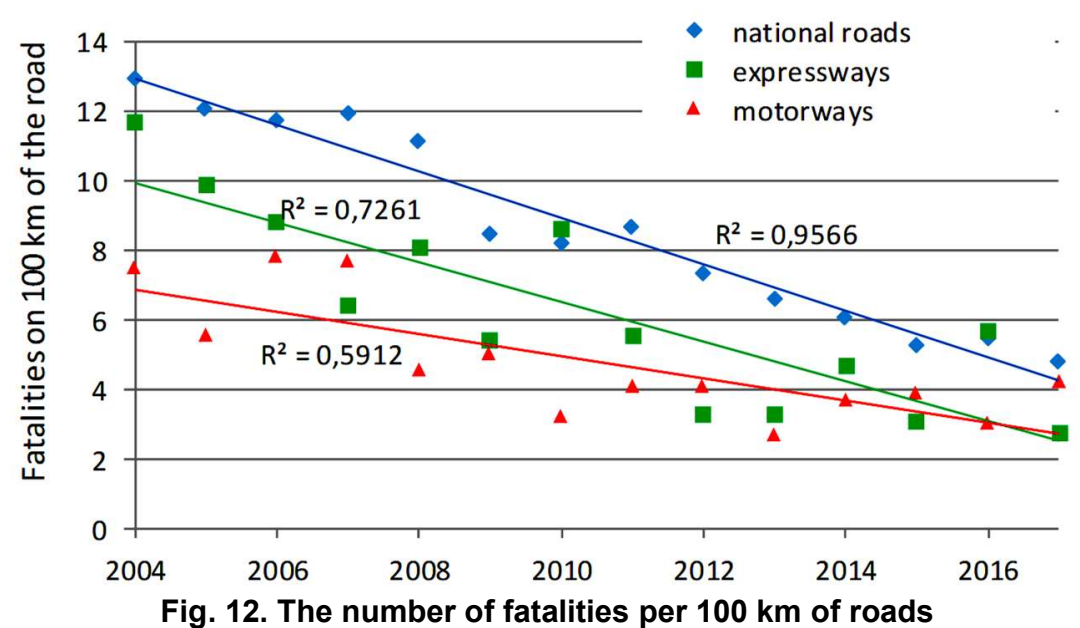

In 2017, 4.8 people per $100 \mathrm{~km}$ were killed per on national roads, while on motorways it was 4.27 and 2.76 on expressways. If we analyse the trend lines, it can be concluded that the possibility of losing a life on expressways and motorways is very similar and lower than on national roads.

In many statistics used to assess the severity of accidents, the rates of fatalities per 100 accidents are applied. A relatively high rate of fatalities per 100 accidents occurs on expressways with high-speed limits (as shown by the trend line, Fig. 13). Over the years, however, there have been very high fluctuations of this rate depending on accident data. In 2015, this rate was the lowest for national roads (14.79), in 2016 for motorways (12.04), and in 2017 for national roads (12.29). It is worth emphasising that the average value of this rate, determined for the total number of accidents, falls annually and in 2017 it was 8.64 and is one of the highest in Europe. However, it is worth noting that in many countries the definitions related to accidents may differ, hence the difficulty in comparing these data directly (Sobolewski M.; 2015; Wach W., et al.; 2016; Karliński et al.; 2016).

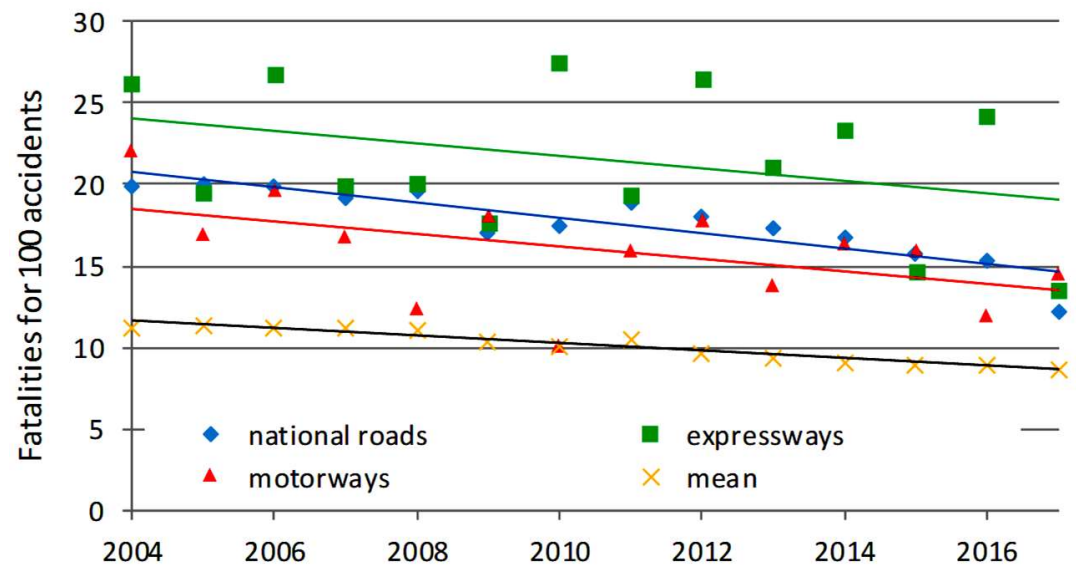

Fig. 13. Accident severity rate expressed in fatalities per 100 accidents in Poland

It is worth stressing that, analysing the trend lines, expressways and then national roads are the worst places in this list, and the safest are motorways. 


\section{CONCLUSION}

Road accidents are unfortunately an inseparable element of road traffic. A driver, a vehicle and an environment, i.e. a road and its infrastructure, have an impact on a road accident occurrence. As a lot has changed in this area in Poland in recent years, a decision has been made to analyse how it affected the level of road safety. The article analyses the accident data in relation to the GAMBIT programs and the National Road Safety Program for the years 2013-2020 implemented during the period considered. A significant decrease in the number of road accidents has been demonstrated and annual changes determined, the value of which ranged from 12.15 to $6.74 \%$. Similarly, statistics on the number of fatalities have been analysed. A midyear drop in the number of fatalities has been determined, i.e.4.4\%. The analysis of accidents on national roads, expressways and motorways has shown that together with the decreasing total number of accidents in Poland, there is a noticeable decline in accidents per 100 kilometres of road. The fatality rate for 100 accidents has also been presented and motorways turned out to be the safest.

\section{REFERENCES}

Police Accidents Reports from 2004-2017, www.policja.pl, online available [Accessed 10.05.2018].

http://europa.eu/rapid/press-release_MEMO-10-343_pl.htm, online available [Accessed 10.05.2018].

https://ec.europa.eu/poland/news/180410_road_safety_pl, online available [Accessed 10.05.2018]

http://europa.eu/rapid/press-release_MEMO-18-2762_en.htm_online available [Accessed 10.05.2018].

http://www.krbrd.gov.pl/pl/2017.html online available [Accessed 10.05.2018].

http://info-car.pl/infocar/artykuly/bezpieczenstwo-na-drogach-1975-2012.html online available [Accessed 05.05.2018].

https://histmag.org/Rynek-motoryzacyjny-w-Polsce-1980-1989-cz.-1.-Co-jezdzilo-po-polskichdrogach-7965 online available [Accessed 10.05.2018].

Jurecki, R. S., Nowak, M., Jaśkiewicz, M. (2014). Analiza bezpieczeństwa ruchu na polskich autostradach i drogach ekspresowych. Logistyka, 6, pp. 4993-5002.

Jurecki, R., Poliak, M., Jaskiewicz, M. (2017). Young Adult Drivers: Simulated Behaviour in a Car-following Situation. PROMET-Traffic\&Transportation, 29(4), pp.381-390.

Jurecki, R., Stańczyk, T.L. (2018). Analyzing driver response times for pedestrian intrusions in crash-imminent situations, Automotive Safety, 2018 XI International Science-Technical Conference, IEEE Conferences, pp. 1-7.

https://www.gddkia.gov.pl/pl/927/drogi-krajowe, online available [Accessed 10.05.2018].

https://www.gddkia.gov.pl/frontend/web/userfiles/articles/s/siec-drog-krajowych-wpolsce_6848/mapa_siec_dk_24_05_2018.pdf, online available [Accessed 10.05.2018].

https://www.gddkia.gov.pl/pl/926/autostrady, online available [Accessed 10.05.2018].

http://www.eurorap.org/partner-countries/poland/, online available [Accessed 19.05.2018].

https://www.nik.gov.pl/aktualnosci/nik-o-dzialaniach-ratowniczych-na-autostradach-i-drogachekspresowych.html, online available [Accessed 10.05.2018].

Sobolewski, M. (2015). Road accidents severity rate in international comparisons (in Polish). Logistyka, 3, pp. 4506-4511.

Wach, W., Gidlewski, M., Prochowski, L. (2016). Reliability of vehicle collision reconstruction based on the law of conservation of momentum and Burg equations. $20^{\text {th }}$ International Scientific Conference TRANSPORT MEANS 2016. Book Series: Transport Means Proceedings of the International Conference, pp. 693-698.

Karliński, J., Ptak, M., Działak, P. and Rusiński, E. (2016). The approach to mining safety improvement: Accident analysis of an underground machine operator, Archives of Civil and Mechanical Engineering, 16(3), pp. 503-512. 